University of Nebraska - Lincoln

DigitalCommons@University of Nebraska - Lincoln

Papers in the Earth and Atmospheric Sciences

Earth and Atmospheric Sciences, Department

\title{
Late Cretaceous to Recent Deformation Related to Inherited Structures and Subsequent Compression within the Persian Gulf: A 2D Seismic Case Study
}

\author{
Caroline M. Burberry \\ University of Nebraska-Lincoln, cburberry2@unl.edu \\ C. A.-L. Jackson \\ Imperial College London \\ J. W. Cosgrove \\ Imperial College London, j.cosgrove@imperial.ac.uk
}

Follow this and additional works at: https://digitalcommons.unl.edu/geosciencefacpub

Part of the Earth Sciences Commons

Burberry, Caroline M.; Jackson, C. A.-L.; and Cosgrove, J. W., "Late Cretaceous to Recent Deformation Related to Inherited Structures and Subsequent Compression within the Persian Gulf: A 2D Seismic Case Study" (2011). Papers in the Earth and Atmospheric Sciences. 290.

https://digitalcommons.unl.edu/geosciencefacpub/290

This Article is brought to you for free and open access by the Earth and Atmospheric Sciences, Department of at DigitalCommons@University of Nebraska - Lincoln. It has been accepted for inclusion in Papers in the Earth and Atmospheric Sciences by an authorized administrator of DigitalCommons@University of Nebraska - Lincoln. 


\title{
Late Cretaceous to Recent Deformation Related to Inherited Structures and Subsequent Compression within the Persian Gulf: A 2D Seismic Case Study
}

\author{
C. M. Burberry, ${ }^{1,2}$ C. A.-L. Jackson, ${ }^{1}$ and J. W. Cosgrove ${ }^{1}$ \\ 1. Department of Earth Science \& Engineering, Imperial College London, Royal School of Mines, South Kensington Campus, London SW7 2AZ, UK \\ 2. Department of Earth \& Atmospheric Sciences, University of Nebraska-Lincoln, Lincoln, NE 68588-0340, USA \\ Corresponding author - C. M. Burberry, email cburberry2@unl.com
}

\begin{abstract}
The Persian Gulf is part of an asymmetric foreland basin related to the Zagros Orogen. Few published studies of this basin and associated onshore areas include seismic reflection data. We present a seismic-stratigraphic interpretation based on marine 2D seismic data, which reveals the presence of two types of compressional structures within the basin: (1) faulted domes related to salt movement and the offshore trace of a NNE-SSW-trending dextral basement fault (the Kazerun Fault); (2) long-wavelength (16 km), low-amplitude (60 ms two-way travel time) folds relating to the advancing deformation front associated with the orogen. Thinning of age-constrained stratal units across structures related to the offshore trace of the Kazerun Fault implies a distinct pulse of uplift on this fault during the Maastrichtian. The geometry of growth strata across other intra-basin structures suggests a second, later stage of deformation, which began in the Middle Miocene. Thickening and folding of post-Middle Miocene stratal units towards the NE (i.e. towards the Zagros Orogen) is interpreted to reflect rapid loading, subsidence and compression related to southwestwards advance of the orogen. The results of this study have implications for the interaction between pre-existing structures and later compressional events both within the Persian Gulf and elsewhere.
\end{abstract}

The Persian Gulf forms part of the Mesopotamian Basin, the foreland basin to the Zagros Orogenic Belt, which is a segment of the central Tethyan deformation belt. The basin is located on the Arabian plate and is currently partly covered by an epicontinental sea. It has been episodically flooded for much of its history (Sharland et al. 2001; Alavi 2004). The Infracambrian Hormuz Complex is an evaporite-rich unit that overlies Precambrian basement at the base of the succession in the Fars zone (Figure 1). This unit is regionally important, acting as a detachment surface for compressional deformation (folding and thrusting) and as the source for many large diapiric structures; all three types of structures are associated with the formation of large hydrocarbon traps in the Persian Gulf region (Edgell 1996).

The "deformation front" associated with the Zagros Orogen is defined as the line separating deformed hinterland from undeformed foreland. A topographic expression of the paleo-deformation front is marked by the Zagros Frontal Fault (Figure 1). Seismicity within the Persian Gulf, to the foreland of (i.e. to the west of) this fault, indicates considerable active deformation to its SW and suggests continued southwestwards migration of the deformation front (Alavi 1994; Berberian 1995; Sattarzadeh et al. 2000; Hessami et al. 2001; Bahroudi \& Koyi 2003; Talebian \& Jackson 2004). Since the onset of ophiolite obduction in the Late Cretaceous followed by continent-continent collision in the Miocene, the location of the deformation front has migrated southwestwards from the Main Zagros Thrust to its estimated current position (Figure 1; Hessami et al. 2001; Bahroudi \& Koyi 2003). This migration is principally documented in the changing location and geometry of depocenters deduced from the onshore study of the post-Cambrian sedimentary sequence overlying the Hormuz Complex (Alavi 1994). Within the present-day
Persian Gulf the overall north-south orientation of structures associated with oil and gas fields, oblique to the present-day deformation front, indicates that the sedimentary sequence at this locality has been relatively undeformed by the Zagros Orogen (e.g. Edgell 1996; Talbot \& Alavi 1996; Konyuhov \& Maleki 2006; Soleimani \& Sabat 2010). Recognizing that the Zagros-related deformation extends beyond the Zagros Frontal Fault (Figure 1) and understanding how and where it does so is important economically, as related structures within the Persian Gulf generated by this deformation may provide hydrocarbon fluid pathways and traps.

This paper uses a 2D seismic dataset from the Persian Carpet 2000 survey, which has a line length of $c .7000 \mathrm{~km}$. The Persian Carpet 2000 survey covers the entire Iranian part of the Persian Gulf and is a dense network of lines designed to provide high-quality 2D data as a basis for all exploration companies applying for Iranian license blocks. A seismic-stratigraphic approach is used to investigate the location and timing of compressional deformation structures within the Persian Gulf, offshore Iran. The quality of these data allows clear reflection events to be assigned across the entire study area and, by tying these to sparse but nearby well data, allows ages to be assigned to these reflections and the seismic unit they bound. Analysis of the structural and stratigraphic relationships between the mapped units allows both relative and absolute ages of deformation events to be identified.

\section{Regional structural framework and deformation of the Za-} gros Orogen

The Mesopotamian Basin formed as a result of loading by thrust sheets associated with the Zagros Orogen along its 


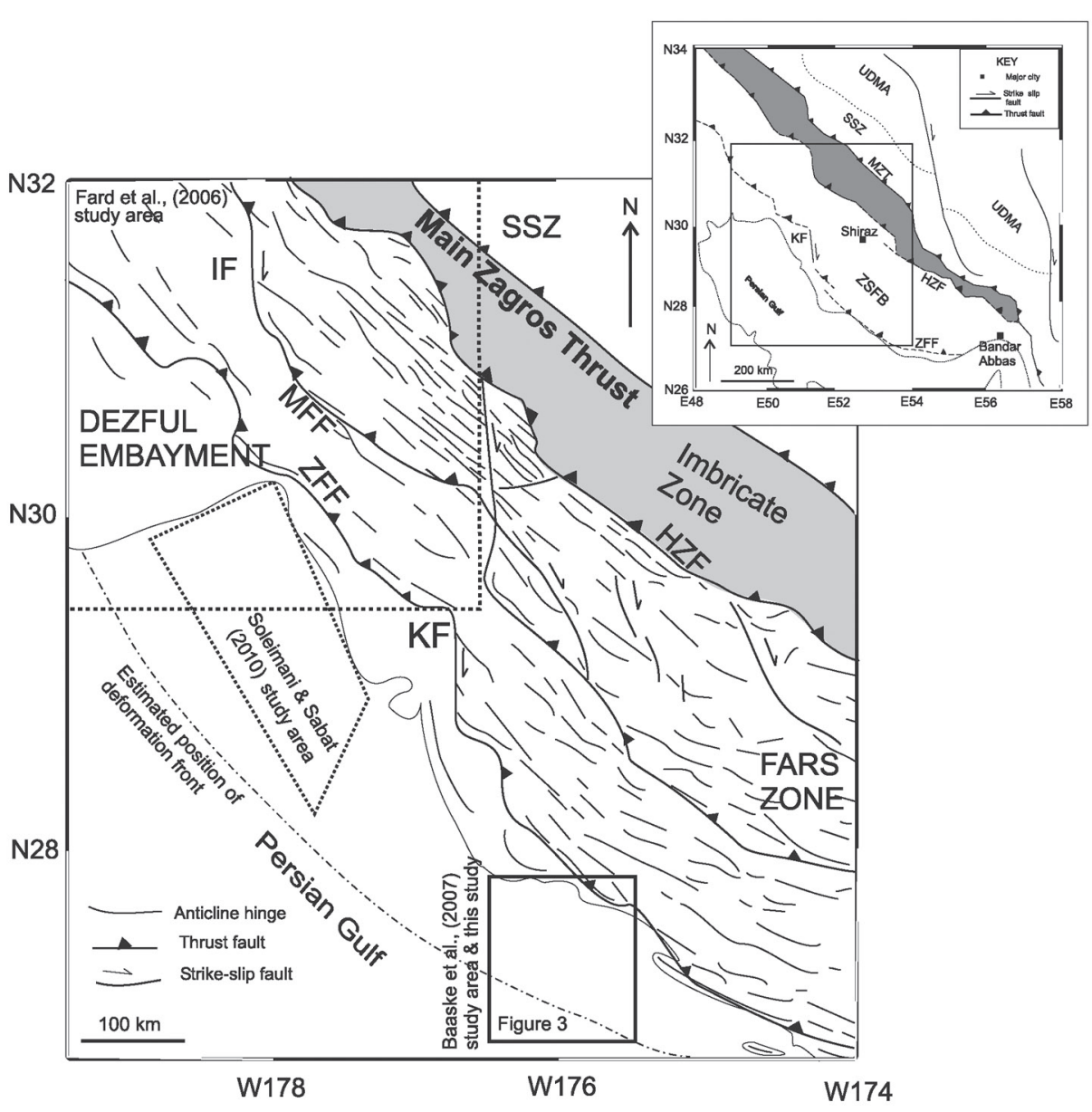

Figure 1. Detailed map of the Zagros study region, with inset showing the wider location. The proximity of the Simply Folded Belt and the block of seismic data used in this study is indicated. Onshore, the trends of the fold lines are marked.

KF, Kazerun Fault

IF, Izeh Fault

UDMA, Urumieh-Dohktar Magmatic Arc SSZ, Sanandaj-Sirjan Zone

HZF, High Zagros Fault

MFF, Mountain Front Fault

MZF, Main Zagros Thrust

ZFF, Zagros Frontal Fault
NE margin (Alavi 1994; Edgell 1996). The Precambrian basement of the Arabian plate formed during the late Pan-African orogenic cycle which lasted from 900 to $610 \mathrm{Ma}$, with the main orogenic phase occurring from 680 to 610 Ma (Jassim \& Goff 2006). Deep-seated, approximately north-south-trending Pan-African faults within the Precambrian basement have been intermittently active as strike-slip faults since their formation in the Late Precambrian (Sharland et al. 2001). A notable period of activity occurred during the Late Cretaceous (e.g. Sepehr \& Cosgrove 2005; Fard et al. 2006; Hessami et al. 2006). The surface expression of the structures includes the NNESSW-trending Kazerun and Izeh Faults (Figure 1). These faults are significant as they (1) separate the belt into distinct tectonostratigraphic regions (see below) (Koop \& Stoneley 1982), (2) localize deformation beneath the lower décollement, (3) influence a zone of more diffuse deformation above this décollement, and (4) form the boundaries of the salt basins in the Hormuz Complex. As such, they provide the loci for diapirism of the salt in successive stress regimes (Edgell 1996; Talbot et al. 2000; Sharland et al. 2001; Cosgrove et al. 2009).

While part of Gondwanaland, the region underwent a period of tectonic quiescence until the opening of the Neo-Tethys in the Permo-Triassic. This produced a series of horsts and grabens that parallel the present NW-SE trend of the belt (Ross et al. 1986; Sepehr 2001). Sea-floor spreading continued throughout the Jurassic and Cretaceous, and resulted in the accumulation of thick Triassic-Cretaceous passive margin sequences on the NE edge of the Arabian platform. In the Mid- to Late Cretaceous, northeastwards subduction of Tethyan crust and obduction of ophiolite slices marked the first phase of Ara- bian plate compression (Haynes \& McQuillan 1974; Sattarzadeh et al. 2000). During this phase of deformation, deep-seated, NNE-SSW-trending basement faults were reactivated as dextral strike-slip faults, in response to the regional NW-SE compression linked to the collision between the Saudi Arabian and Iranian plates, with salt diapirism occurring at dilational jogs along these structures (e.g. Edgell 1996; Talbot \& Alavi 1996; Talbot et al. 2000; Fard et al. 2006; Hessami et al. 2006; Ahmadhadi et al. 2007; Cosgrove et al. 2009). The Tethyan Ocean finally closed in the Miocene, with the onset of Zagros-type, predominantly compressional deformation occurring in the Mid-Miocene (Stoneley 1981; Swift et al. 1998; Agard et al. 2005).

The Zagros Orogen can be divided into the UrumiehDokhtar Magmatic Arc, the Sanandaj-Sirjan Zone and the Zagros Simply Folded Belt (Alavi 1994; Figure 1). The Simply Folded Belt, which is situated between the High Zagros Fault and the Zagros Frontal Fault, consists of NW-SE-trending, periclinal folds. These change from gentle and open in the SW to closed and locally overturned in the NE (Alavi 1994). Marked changes in the type and distribution of deformation also occur along the strike of the Simply Folded Belt; for example, the wide zone of relatively open folding that characterizes the Fars region contrasts markedly with the narrow zone of folding in the adjacent Dezful Embayment (Figure 1). These changes coincide with important basement faults such as the NNE-SSW-trending Kazerun Fault (Sattarzadeh et al. 2000; Bahroudi \& Talbot 2003; Walpersdorf 2006; Sepehr \& Cosgrove 2007).

Miocene compression within the Zagros Simply Folded Belt was coeval with the opening of the Red Sea and associated uplift of the Arabian platform. Shortening across the Zagros Sim- 
ply Folded Belt occurred at a rate of $20 \mathrm{~mm} \mathrm{a}^{-1}$ (Ross et al. 1986; Vita-Finzi 2001). Active deformation within the Zagros Simply Folded Belt is dominated by folding above various subsurface detachments (described below). The variable aspect ratio of the anticlines implies that some folds represent fault bend folds whereas others represent detachment folds (Blanc et al. 2003). During the Pliocene, the development of major anticlines and uplifted thrust slabs marked a major period of SW migration of the deformation front when the Zagros Simply Folded Belt became raised above sea level (Sattarzadeh 1997). Holocene fault movements imply that there is periodicity in the slip on many of the thrusts, with the last major uplift event in the Zagros Simply Folded Belt occurring around 1700 BP (Lees 1955). Recent regional movements are indicated by the presence of prominent river terraces, the arching of a canal that cuts through the currently growing Shaur Anticline (Lees 1955) and numerous observations from global positioning system (GPS) studies (e.g. Alavi 1994; Berberian 1995; Sherkati \& Letouzey 2004; Hessami et al. 2006; Walker 2006).

\section{Tectonostratigraphic evolution of the Persian Gulf}

The study area considered in this paper is located offshore from the Fars Zone, Iran (Figure 1), thus nomenclature based on Fars stratigraphy and timing has been used (James \& Wynd 1965; Sharland et al. 2001). Following O'Brien (1957) the thick (around $10 \mathrm{~km}$ ) sedimentary succession beneath the Persian Gulf is divided into a lower mobile group (the Hormuz Complex), a competent, carbonate-dominated group (PaleozoicMesozoic), an upper mobile group (Miocene shales and evaporites) and an upper incompetent group (Plio-Pleistocene clastic deposits) (Figure 2).

The Infracambrian Hormuz Complex, composed of evaporites, local dolomites and limestones, siliciclastic deposits and, in its upper parts, interlayered volcanic horizons, was deposited within a series of early Cambrian north-south-trending grabens and Infracambrian NW-SE-trending half-grabens and early Cambrian NNE-SSW-trending grabens. This unit forms the major basal detachment for much of the later compressional deformation within the Fars region (Talbot \& Alavi 1996). Deposition of the Hormuz Complex was followed by deposition of clastic material until the Early Permian, although much of the associated sediment has been eroded from the Fars region during later uplift associated with the Hercynian Orogeny (Sharland et al. 2001). The Permian and Triassic periods were characterized by the deposition of shallow-marine carbonates of the Dalan, Khangan and Khaneh Kat formations, with interbedded evaporite horizons of the Dashtak Formation during the Late Triassic. The Jurassic period is characterized by deposition of another carbonate-dominated sequence comprising platform carbonates of the Surmeh and Najmeh formations, which overlie the Neyriz Formation siltstone at the base (Beydoun et al. 1992; Sharland et al. 2001; Sepehr \& Cosgrove 2005; Fard et al. 2006). The Hith anhydrite caps the Jurassic sequence and is overlain by another massive limestone sequence, the Fahliyan Formation. The Fahliyan Formation grades into the Gadvan Formation, which in turn is overlain by the Dariyan Formation (Alavi 1994).

During the Late Cretaceous, a series of foreland basins developed in response to initial thrusting and ophiolite emplacement; this resulted in the formation of an unconformity between the Dariyan and overlying units. The Albian-Turonian sequence is characterized by the deposition of platform carbonates of the Sarvak Formation, which is underlain by the carbonate-shale sequence of the Kazhdumi Formation (James \& Wynd 1965; Koop \& Stoneley 1982; Alavi 2004; Sepehr \& Cosgrove 2007). The Turonian-Maastrichtian sequence, bounded by unconformities, comprises the pro-foreland megasequence (Gurpi, Ilam and Laffan formations). The Gurpi Formation consists of argillaceous lime mudstones, and the Laffan and Ilam are carbonate- and shale-dominated (James \& Wynd 1965; Koop \& Stoneley 1982; Alavi 2004; Sepehr \& Cosgrove 2007). Unloading and denudation in the inner parts of the orogen and progressive migration of deformation towards the SW occurred from the Paleocene to Oligocene (Alavi 2004). The Pabdeh Formation was deposited in the axis of the flexural basin created during deformation migration, whereas the Jahrum Formation is used to define units deposited in shallower, more marginal basin areas (Nadjafi et al. 2004). The Oligo-Miocene Asmari Formation, a well-bedded shelly limestone deposited unconformably on the Jahrum Formation (Alsharhan \& Nairn 1995; Nadjafi et al. 2004), forms the erosion-resistant carapaces to many of the periclines seen onshore (e.g. Haynes \& McQuillan 1974; Berberian 1995; McQuarrie 2004). Deposition of the Asmari Formation occurred before major loading of the plate by the Zagros Simply Folded Belt. In parts of the basin, the Asmari Formation is unconformably overlain by the Gachsaran Evaporite, after which the developing foreland basin was filled with the marls and interbedded limestones of the Mishan Formation (James \& Wynd 1965; Alsharhan \& Nairn 1995). Material derived from erosion of the uplifting Simply Folded Belt was deposited in the foreland basin during the Pliocene-Recent. This is represented lithostratigraphically by the Agha Jari clastic unit (James \& Wynd 1965; Alsharhan \& Nairn 1995) and the overlying Bakhtiari Conglomerate. The post-Asmari Formation units thicken to the NE within the study area, as a result of deepening of the basin in response to loading from the southwestwards advancing Zagros Orogen (Swift et al. 1998).

\section{Dataset, seismic stratigraphic framework and methods}

A grid of 2D seismic data (line length $c .7000 \mathrm{~km}$ and line spacing c. $2.5 \mathrm{~km}$ ) offshore from the Fars Zone (Figures 3 and 4) has been interpreted to determine the structural style and timing of deformation within the Persian Gulf associated with recent migration of the Zagros Deformation Front. These data are in two-way travel time (TWT) and no depth conversion has been applied. However, given that the units of interest are above the major evaporite horizons, lateral velocity variations in the overburden are minimal and assumed not to significantly affect the structural interpretation. Exploration wells in the NW of the survey region (Swift et al. 1998) were used to pick a total of eight horizons of known age across the region, as well as one arbitrary horizon. These wells are locally known as IMD-1 and IE-1, but are referred to as D-1 and E-1 in line with the nomenclature published by Swift et al. (1998). The horizons of known age are top Miocene, top Asmari, top Jahrum, top Maastrichtian, top Turonian, top Albian, top Jurassic and top Triassic (Figure 5). An arbitrary horizon was mapped within the Pliocene sequence, to investigate thickness changes within the post-Miocene sediments. The TuronianMaastrichtian pro-foreland basin sequence is marked by distinct NE-dipping clinoforms (Figure 4). The top Asmari, top Jahrum, top Maastrichtian, top Turonian and top Triassic reflections are all unconformities within the sedimentary pile and correspond to unconformities mapped or described by other workers (e.g. Alsharhan \& Nairn 1995; Uchupi et al. 1996; Swift et al. 1998). 


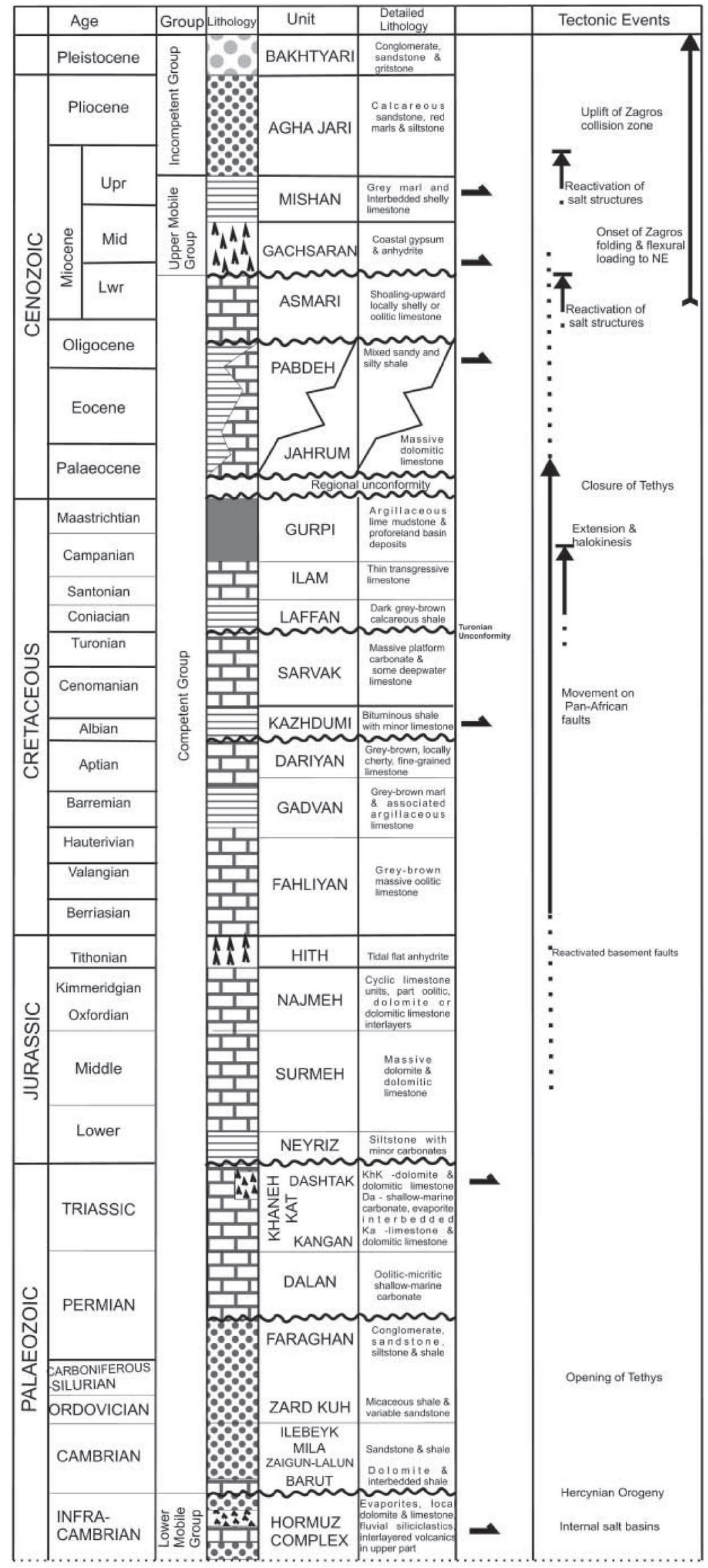

Figure 2. Tectonostratigraphic column showing lithologies present in the Fars region and offshore, as well as the relative timing of orogenic and halokinetic events. Half-arrows indicate potential detachment horizons. (Compiled from references listed in this paper, with particular emphasis on Beydoun et al. 1992; Sharland et al. 2001; Sepehr \& Cosgrove 2005; Fard et al. 2006.) 


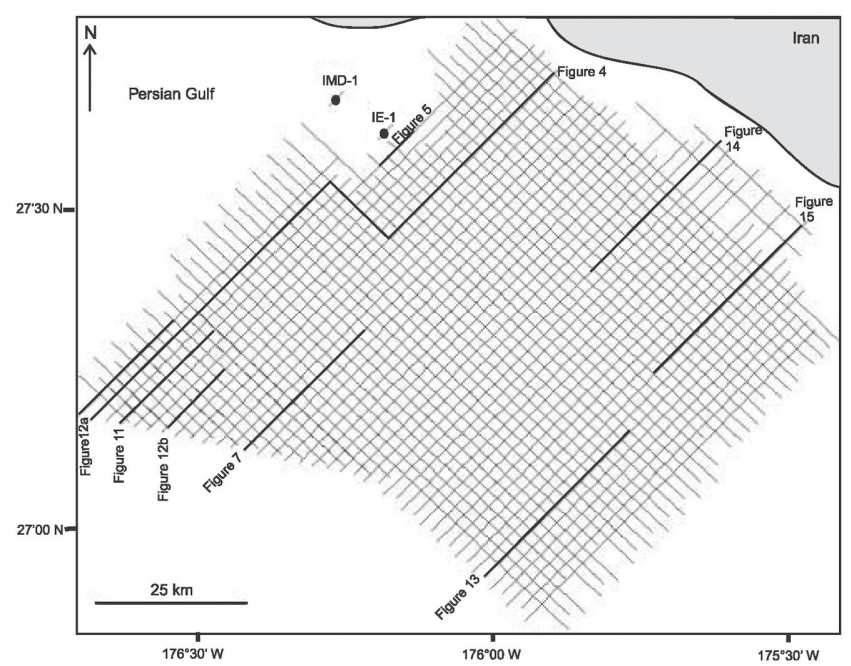

Figure 3. Seismic base map, showing both the locations of lines used in this study and those illustrated in the subsequent figures.

\section{Structural description}

Overall, strata within the study area dip gently to the NE, towards the onshore Simply Folded Belt. This regional dip is locally disturbed by a series of structures, visible most clearly on the top Triassic horizon (Figure 6). These structures (A, B, $\mathrm{E}$ and $\mathrm{K}$ ) as well as the Golshan structure and the South Pars Field are labelled following conventions within the exploration community of the Persian Gulf (e.g. Bordenave 2003). The
Golshan structure and the South Pars Field are known hydrocarbon accumulations, and A, B, E and $\mathrm{K}$ represent current exploration targets. As well as these structures, an additional two faulted zones (here labelled $\mathrm{X}$ and $\mathrm{Z}$ ) are observed in the NE of the dataset. Lastly, low-amplitude folds are visible in the NE part of the seismic grid, folding all interpreted horizons from the top Triassic to the top Miocene. The geometry, scale and distribution of these structures are described below.

\section{$K$ and E structures}

These structures (Figure 6) form part of a NNE-SSW trend located within the central part of the dataset. On a time-structure map of the top Triassic, the K structure and E structure appear as separate culminations, although they lie on a more elongate, NNE-SSW-trending structure (Figure 6). The K structure is a $35 \mathrm{~km}$ long, NNW-SSE-trending dome, which is dissected by three fault sets, labelled K-1, K-2 and K-3 in Figure 6. The first of these sets (set K-1) trends NW-SE to the west and WNW-ESE along-strike to the east. The major fault dips gently to the SW and has an offset of $30 \mathrm{~ms}$ TWT. A series of antithetic faults develop along the length of this major fault. The second fault set (set K-2) is oriented NNW-SSE. These faults dip gently to the SW and display displacements of 20 ms TWT. Lastly, a third fault set (set K-3), which is oriented ESE-WNW, has been mapped directly to the east of the $\mathrm{K}$ structure. The faults are gently dipping, and form a small ESE-WSW-trending graben with offsets of $c$. $10 \mathrm{~ms}$ TWT on each fault. All three fault sets (K-1, K-2 and K-3) offset Early Cretaceous and older units only.

The E structure is a $15 \mathrm{~km}$ diameter sub-circular dome, with two ESE-WNW-trending faults mapped directly to the east.
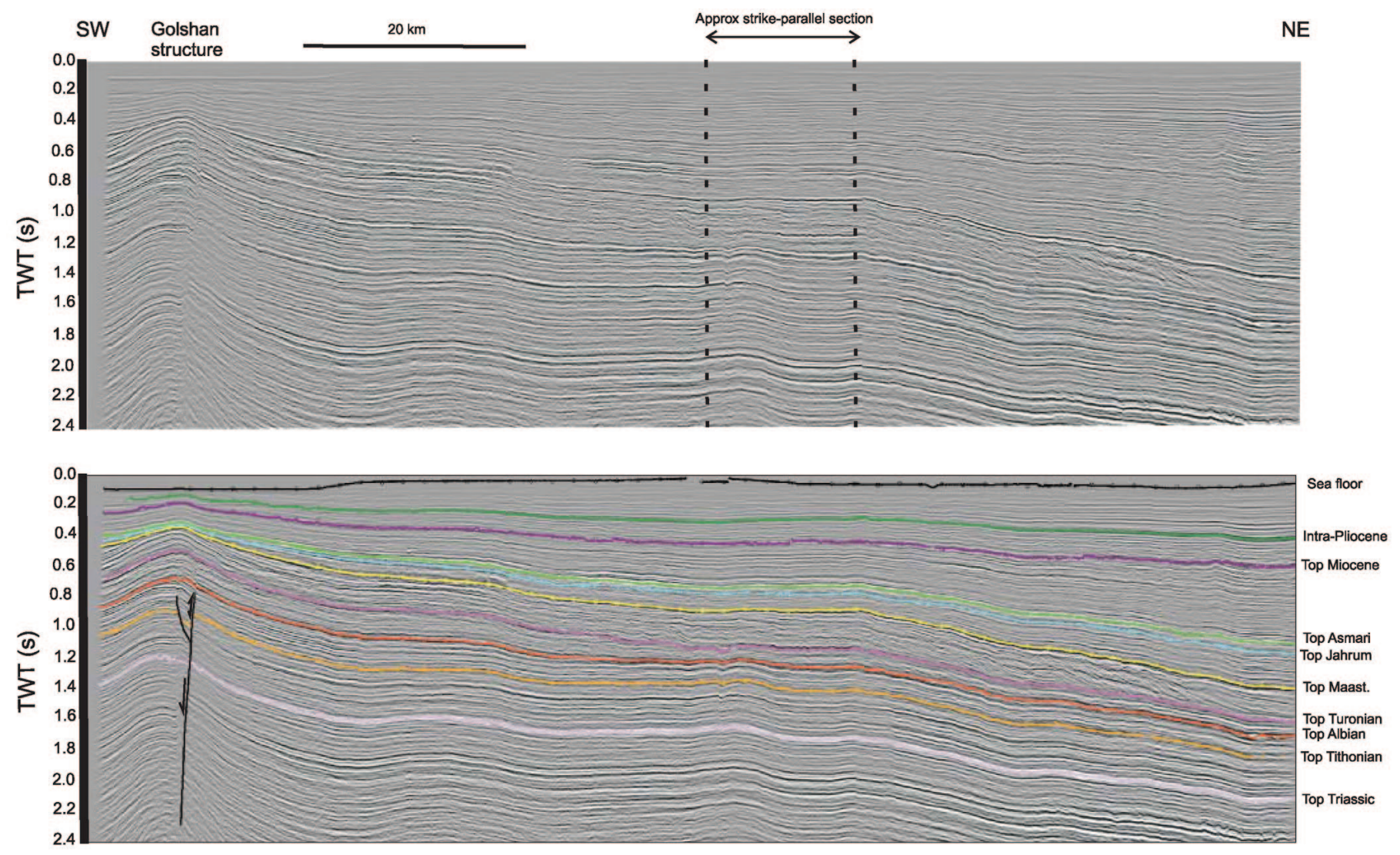

Figure 4. Regional seismic line and overlain interpreted horizons. The location of this line is shown in Figure 3. The vertical exaggeration is $c .6 \times$. 


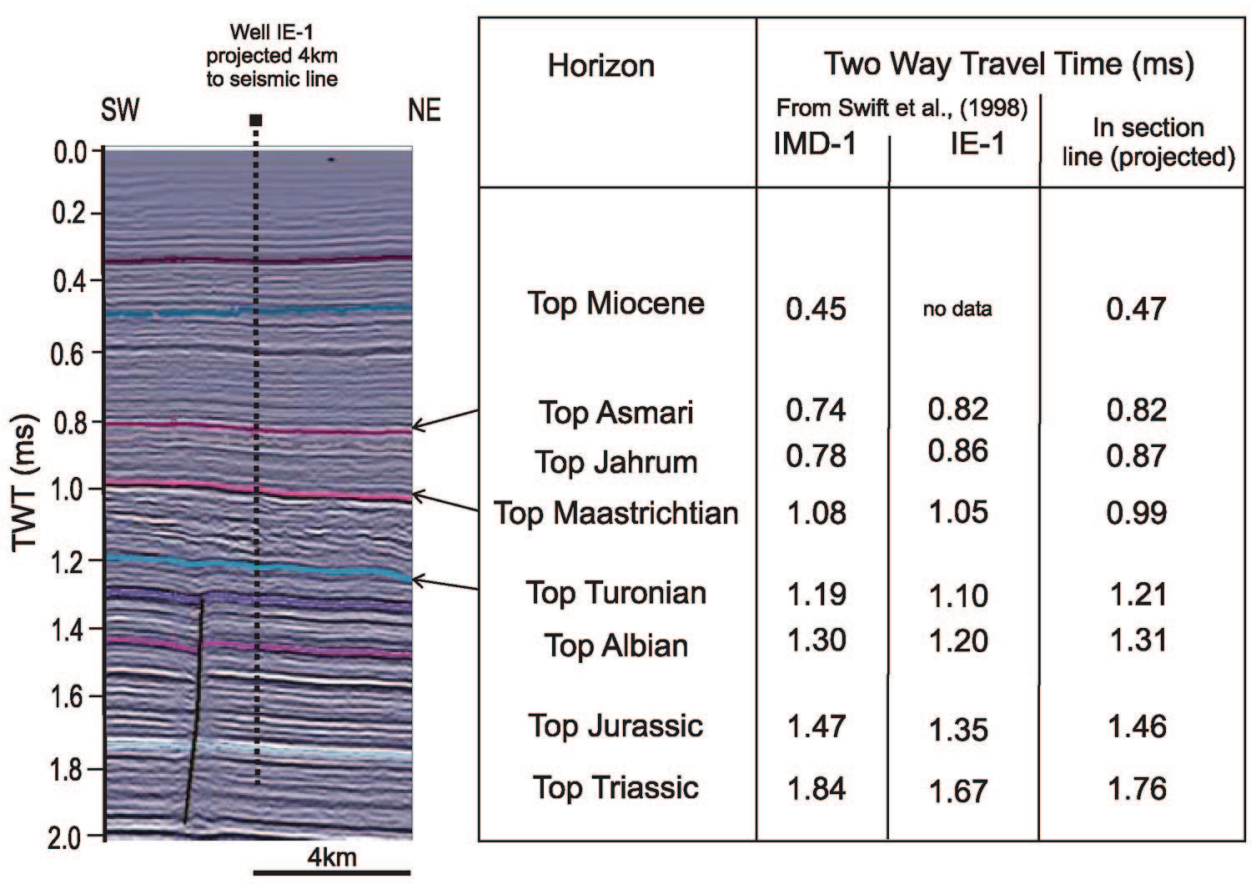

Figure 5. Horizons are identified projected from TWT formation tops in wells IMD-1 and IE-1. Correct identification of horizons was enhanced in discussion with S. Sherkati and by comparisons with horizon picks in Swift et al. (1998). The location of this seismic section is indicated in Figure 3.

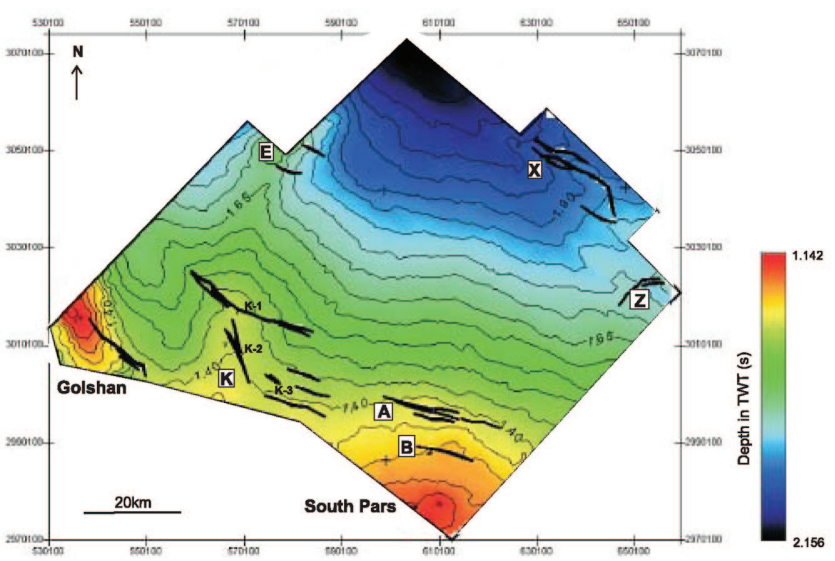

Figure 6. Top structure map drawn on the interpreted top Triassic horizon. All structures referred to in the text are labeled in bold, and specific fault sets are also labeled.

These faults have displacements of $20 \mathrm{~ms}$ TWT and dip to the SW. The faults are at least $5 \mathrm{~km}$ in length, extending eastwards away from the crest of the E structure to the edge of the dataset, and again, offset the Lower Cretaceous and older units only.

Thickness changes in the Jurassic package, across the Kstructure faults, are in agreement with the small offsets on each of these faults, which have been described above (Figures $7 \& 8 \mathrm{a})$. Thickness changes in the overlying Early Cretaceous package are more complex, with thinning across the $\mathrm{K}-1$ fault system, onto the main K structure (Figures 7 \& 8b). There is a further subtle thinning to the east of a NNE-SSWtrending lineament (black dashed line in Figure 8b-d) located directly to the west of the K structure. Within the Middle Cretaceous package, thinning of $c .30 \mathrm{~ms}$ TWT is noted across the NNE-SSW-oriented, $\mathrm{K}$ and E structural trends (Figure 8c). Above this, the Late Cretaceous package thickens across the NNE-SSW-trending lineament close to the K structure, with a thickness increase of $40 \mathrm{~ms}$ TWT to the west of this lineament (Figure 8d).
Post-Maastrichtian, the Paleocene-Eocene package thins subtly across the NNE-SSW trend linking the K and E structure (Figure 9a). However, the dominant thickness trend in the Mid- to Late Miocene is of thickening towards the Zagros Frontal Fault (Figure 9b). Within the Late Miocene-Recent package, there is slight thinning across the $\mathrm{K}$ structure, but the dominant thickness trend is again thickening towards the Zagros Frontal Fault (Figure 9c). Temporal changes in the thickness of various stratigraphic units across the $\mathrm{K}$ structure are constrained through analysis of a thickness ratio, whereby the thicknesses of various units are measured and compared between the crest and flank of the structure (dummy well locations are illustrated in Figure 7 and data are summarized in Table 1). For example, a ratio of 0.5 indicates $50 \%$ thinning of sediment from the flank to the crest of the structure. These data are also summarized graphically in Figure 10, indicating that two episodes of maximum thinning occurred across the $\mathrm{K}$ structure, one during the Late Maastrichtian and the other during the Miocene. In addition, periods of structural inactivity are documented in Late Oligocene-Early Miocene times and the latest Maastrichtian, the latter being associated with eventual cessation of activity on the structure.

\section{Golshan structure}

This structure is located in the SW corner of the seismic grid and is only partially imaged. The structure as mapped on the top Triassic horizon defines a NNW-SSE-trending pericline that is related to an underlying NW-SE-trending fault (the Golshan fault; Figure 11). The fold is c. $20 \mathrm{~km}$ long and up to $10 \mathrm{~km}$ wide. As stated above, only a portion of this structure is imaged within the study area, and the structure is known to continue towards the NW outside the present dataset (J. Erickson, pers. comm.; S. Sherkati, pers. comm.). NW-SE faults dissect the fold, offsetting the top Albian and younger reflections (Figure 11). These faults consist of a master fault, the Golshan fault, which dips to the SW, and a series of NE-dipping, antithetic faults that splay off the master fault (Figure 12). The master fault shows normal offset of the top Tithonian horizon, 


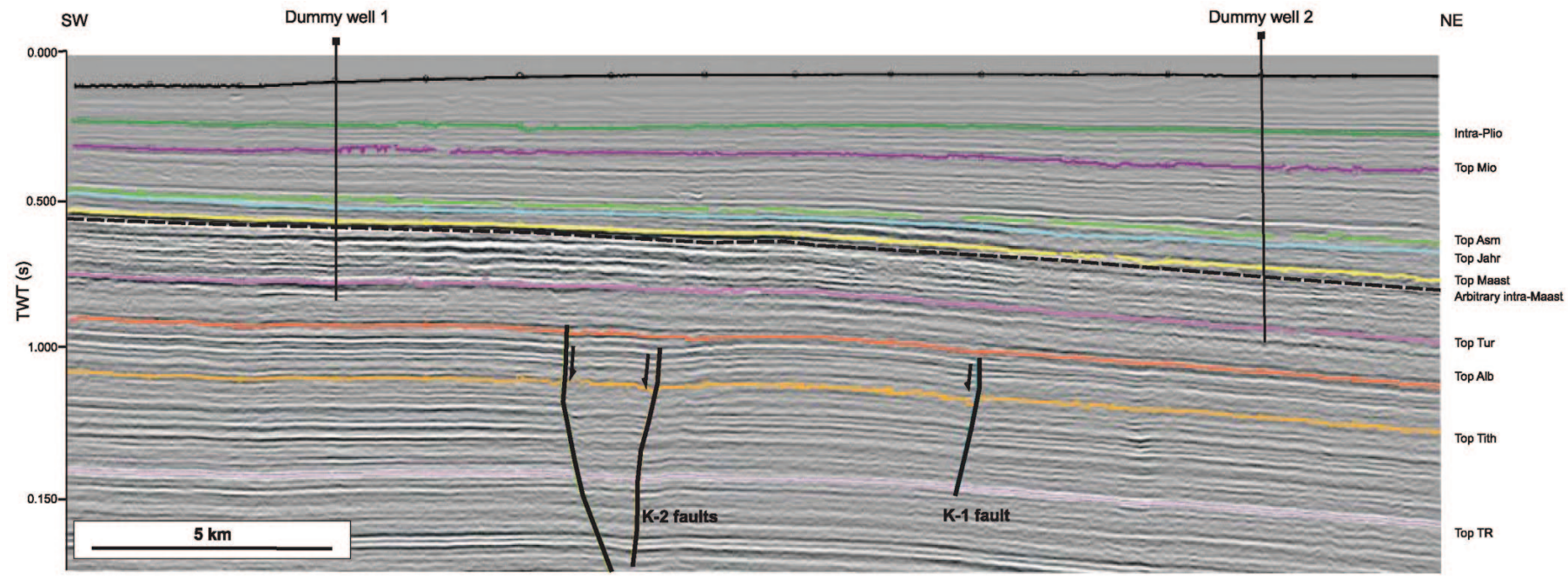

Figure 7. Seismic line across K structure (location shown in Figure 3). The dummy wells used in Figure 10 and Table 1 are also indicated. The vertical exaggeration of this line is $c .4 \times$.
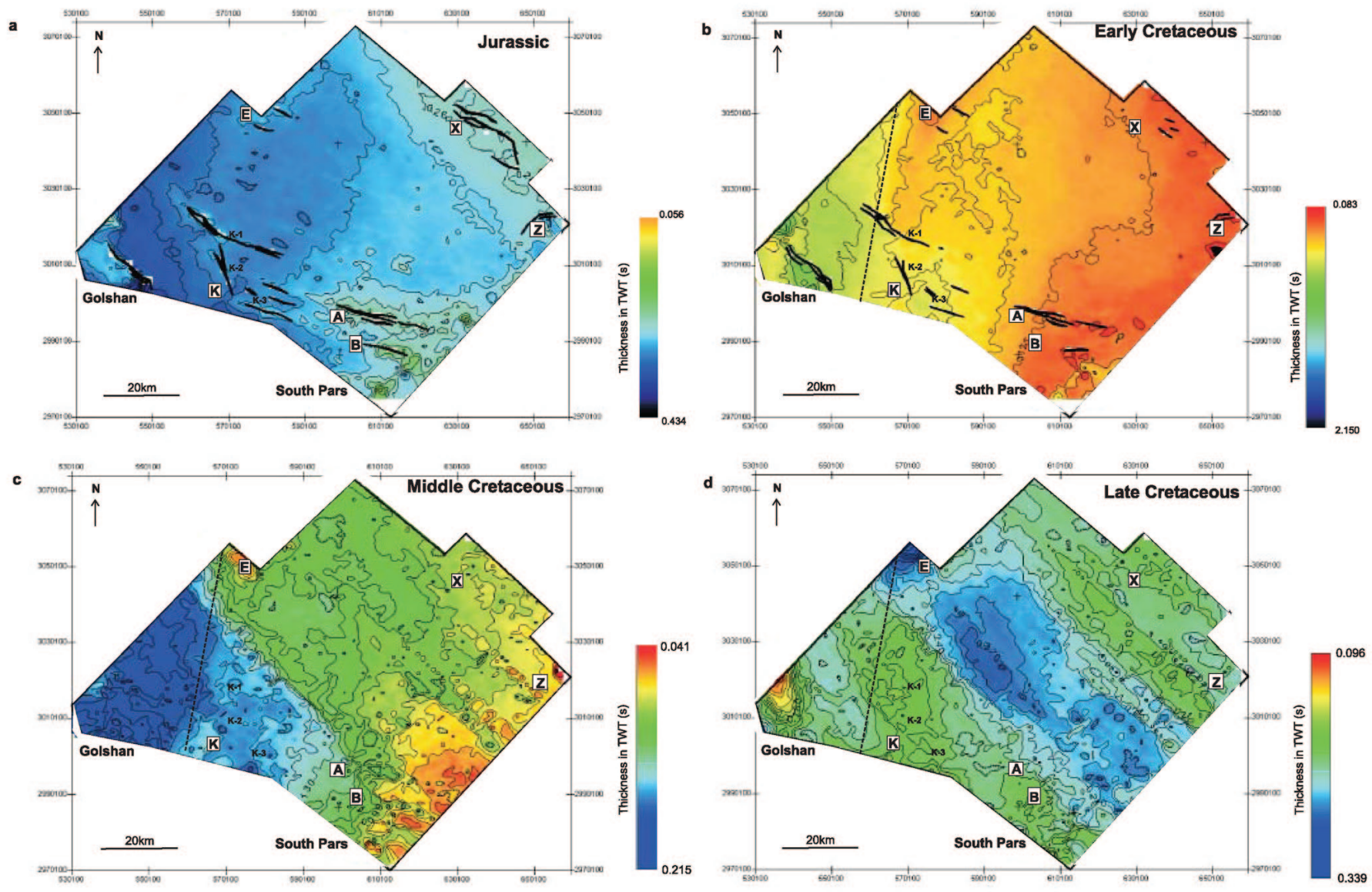

Figure 8. Isochron maps for time periods between the top Triassic and top Maastrichtian mapped horizons.

but folding on the top Albian horizon, indicating inversion on this fault. Below $1.9 \mathrm{~s}$ TWT, reflectors become more chaotic and the exact nature of the structure at depth is unclear. Lowamplitude, chaotic reflections events at $7 \mathrm{~s}$ TWT may indicate that the Golshan structure and associated faults are underlain by a deep-seated, Hormuz Complex-related salt structure (see Baaske et al. 2007).

Thickness changes and seismic-stratigraphic relationships of the Jurassic-Cretaceous interval across the Golshan structure and associated faults are complex. The Jurassic package 
a
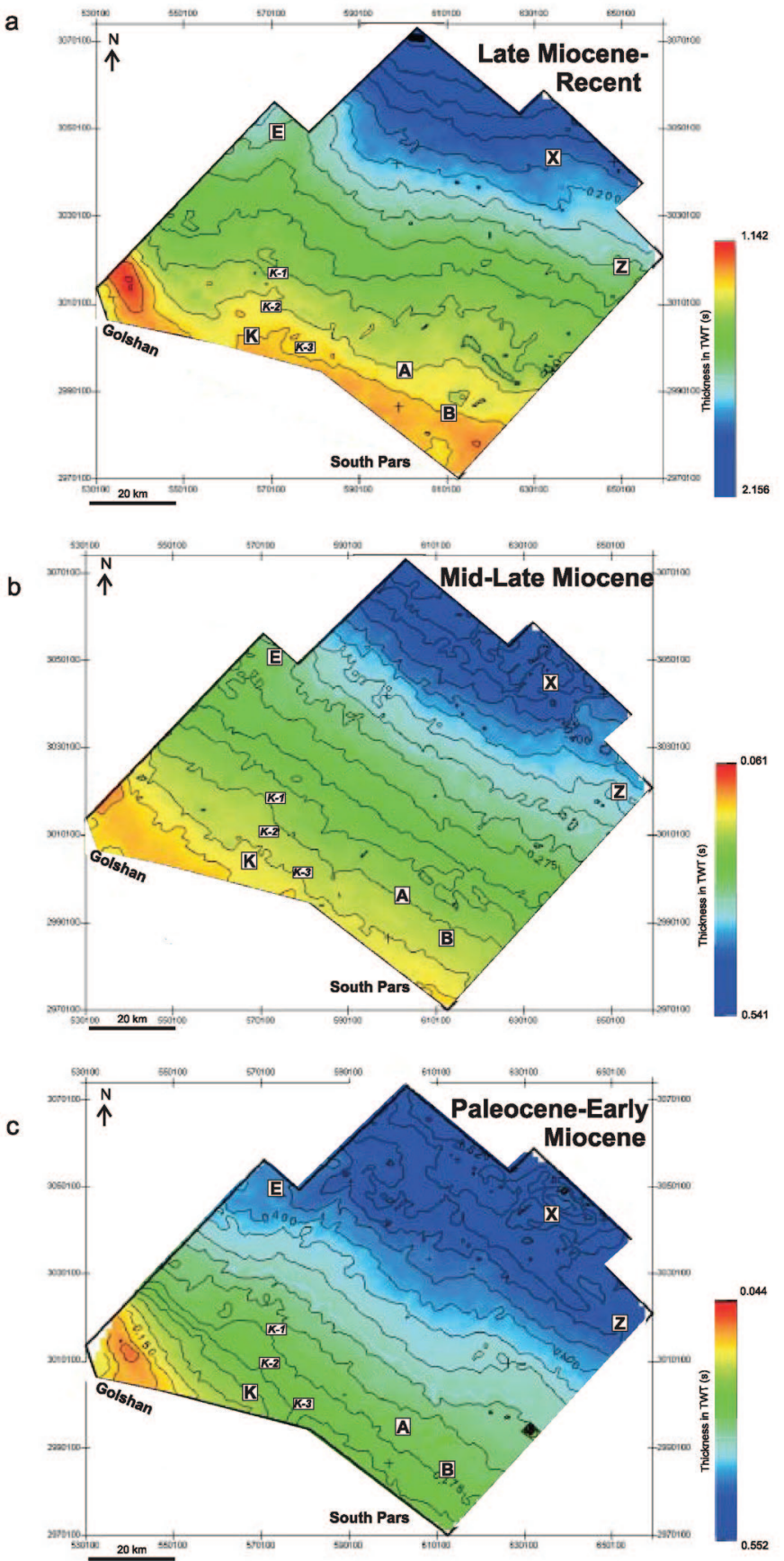

Figure 9. Isochron maps for time periods between the top Maastrichtian mapped horizon and the sea floor (representing the limit of sedimentation in Recent time).

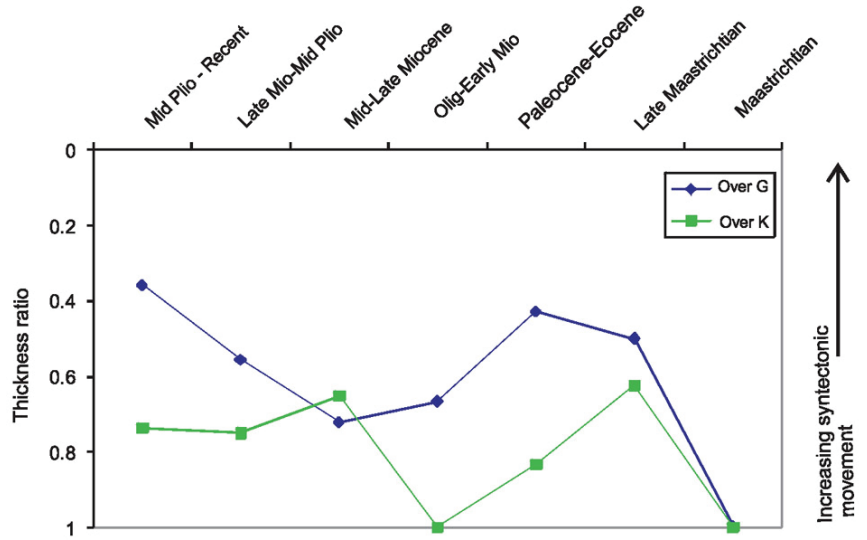

Figure 10. Thickness ratio change across the $\mathrm{K}$ and Golshan structures. The raw data are given in Tables 1 and 2 respectively.

thins to the SW across the Golshan fault (Figure 8a) whereas the overlying Early Cretaceous package thickens to the SW across the Golshan fault (Figures $8 \mathrm{~b}$ and 11). The Late Cretaceous units show minimal thickness change across the Golshan structure (Figure $8 \mathrm{c}$ and d), but the Paleocene-Early Miocene package thins by $40 \mathrm{~ms}$ (TWT) across the structure (Figure 9a). The Mid- to Late Miocene and Late Miocene-Recent packages also thin across the Golshan structure (Figure $9 \mathrm{~b}$ and c). Table 2 summarizes the thickness changes across the Golshan structure by means of thicknesses measured in two dummy wells whose locations are illustrated in Figure 11 and the results of which are shown graphically in Figure 10 (see method described above). The thickness ratio is always less than one, indicating continuous differential compaction, but low values of the thickness ratio during some time periods indicate additional activity. Two periods of prominent activity are observed on the Golshan structure; one during the late MaastrichtianEarly Oligocene, and one from the Late Miocene to Recent.

The Early Cretaceous hanging-wall fill of the Golshan fault has been deformed in later tectonic activity. At the NW end of this fault, the Early Cretaceous hanging-wall fill and the overlying Mid- to Late Cretaceous packages are uplifted and folded (Figure 12). In contrast, towards the SE end of the fault, the hanging-wall fill is neither uplifted nor folded but is deformed by a series of steep, NE-dipping faults that splay off the Golshan fault, each with an offset of 10 ms TWT (downthrow to the NE).

\section{South Pars, A and B structures}

The A and B structures are characterized by a series of faults that lie along-strike from the WNW-ESE-trending faults delineating the SE margin of the K structure (Figure 6). The

Table 1. Raw data for thickness ratio change across the K structure

\begin{tabular}{|c|c|c|c|c|c|}
\hline Marker & $\begin{array}{l}\text { Dummy well 1, } \\
\text { formation top (TWT) }\end{array}$ & $\begin{array}{l}\text { Column } 1 \\
\text { thickness (s) }\end{array}$ & $\begin{array}{c}\text { Dummy well 2, } \\
\text { formation top (TWT) }\end{array}$ & $\begin{array}{l}\text { Column } 2 \\
\text { thickness (s) }\end{array}$ & $\begin{array}{c}\text { Thickness } \\
\text { ratio }\end{array}$ \\
\hline Sea floor & 0.09 & & 0.06 & & \\
\hline Intra-Pliocene & 0.23 & 0.14 & 0.25 & 0.19 & 0.74 \\
\hline Top Asmari & 0.47 & 0.15 & 0.6 & 0.23 & 0.65 \\
\hline Top Jahrum & 0.51 & 0.04 & 0.64 & 0.04 & 1.00 \\
\hline Top Maastrichtian & 0.56 & 0.05 & 0.7 & 0.06 & 0.83 \\
\hline
\end{tabular}


Figure 11. Seismic line across Golshan structure (location shown in Figure 3). The dummy wells used in Figure 10 and Table 2 are also indicated. The vertical exaggeration of this line is $c .4 \times$.

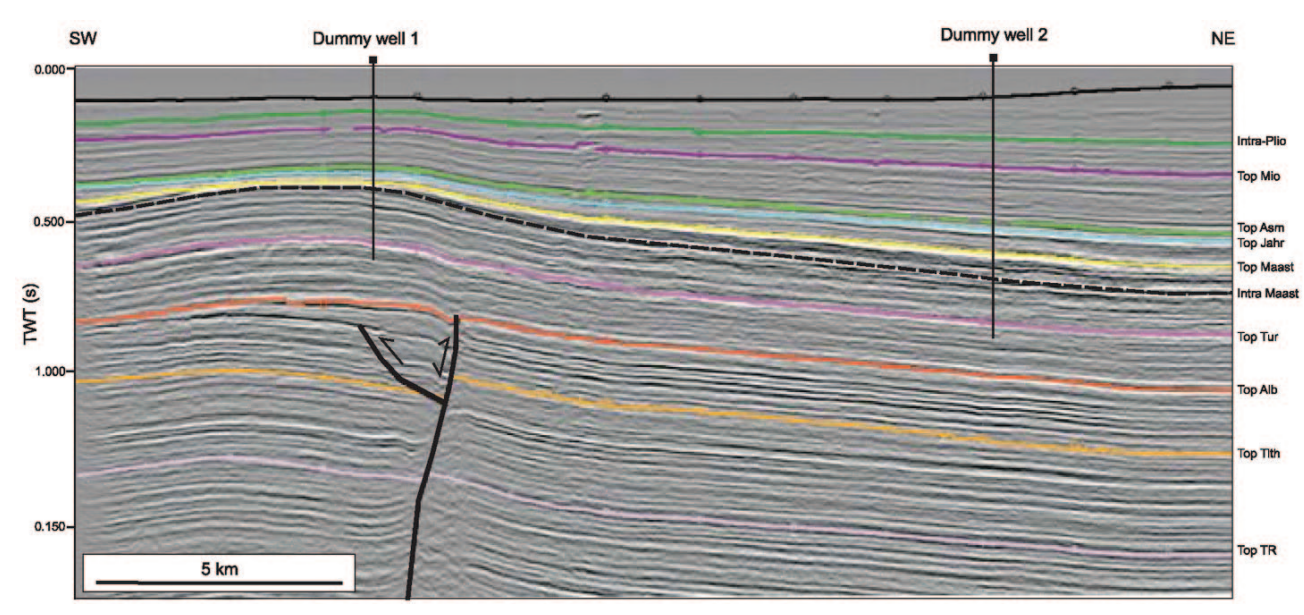

NE

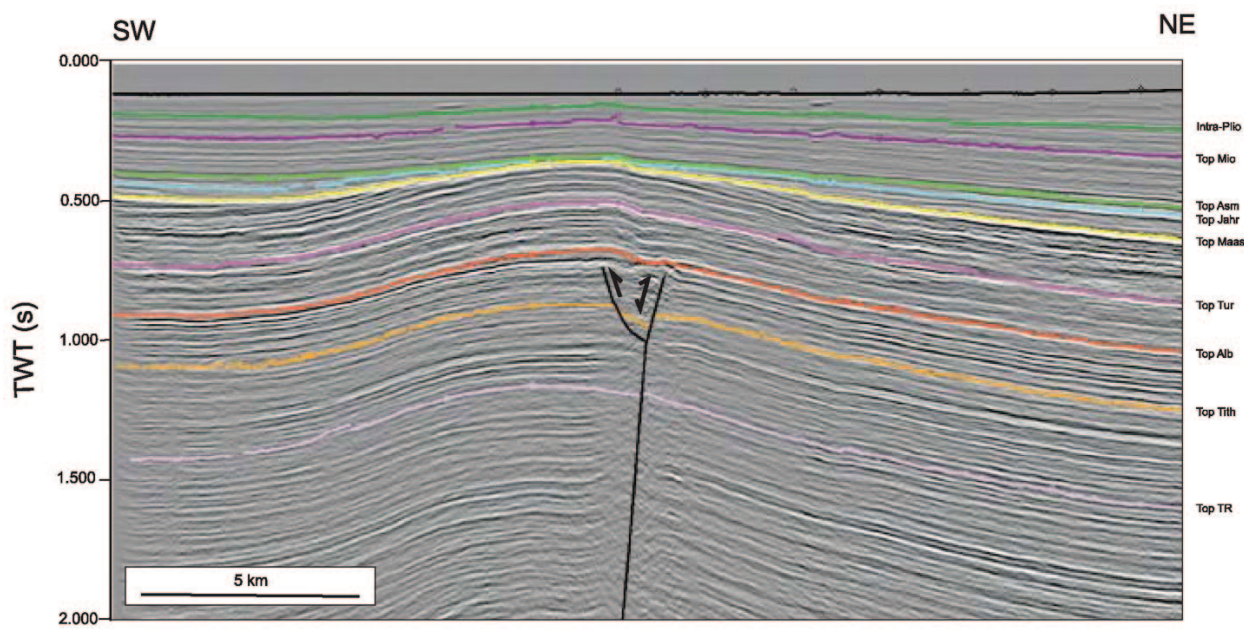

Figure 12. Seismic lines across the mapped NW and SE limits of the Golshan structure, indicating the change in faulting style along this structure. The vertical exaggeration of these lines is $c$. $4 \times$.

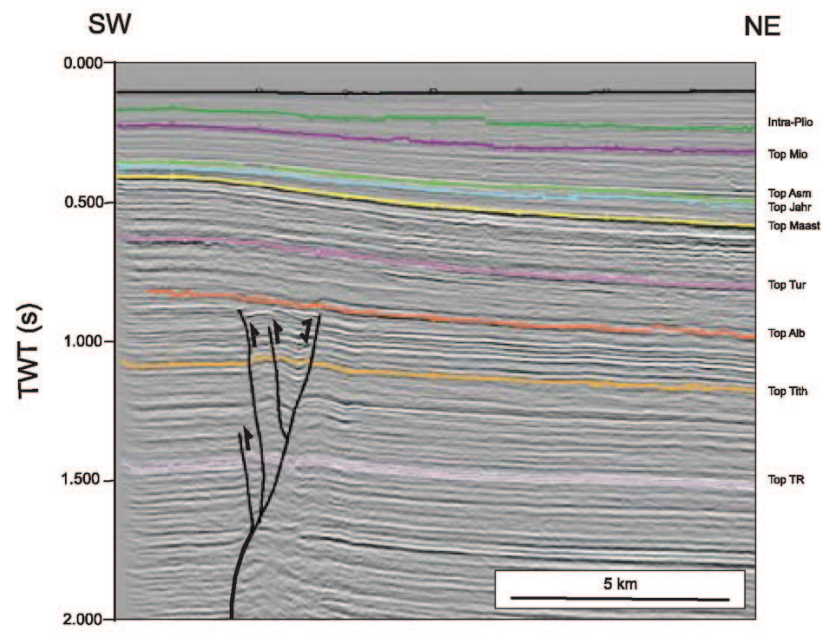

maximum displacement on faults associated with the A and B structures is $25 \mathrm{~ms}$ TWT. Faults forming the A structure bound a small graben, offsetting horizons older than the top Albian (Figure 13). The South Pars Field structure is only partially imaged in the dataset but appears to be characterized by a subcircular, dome-shaped closure (Figure 6; Bordenave 2003; Aali et al. 2006).

The isochron map in Figure 8a indicates a slight thinning of the Jurassic sedimentary package over the South Pars Field structure. Within the Early Cretaceous package, there is thickening to the SW of the A and B fault structures (Figure 13), and further over the South Pars Field (Figure 8b) although the overall trend is that this package thins to the east, towards the Qatar-Fars Arch (Baaske et al. 2007). During the Middle Cretaceous, the graben formed by the antithetic faults of the A systems is infilled by the sediments deposited during this period, causing a thickness increase of $30 \mathrm{~ms}$ TWT between these faults. Also of interest during this period is the NW-SE-trending lineament developed directly NW of the A and B structures, where a prominent change in the thickness of the Lower Cretaceous package is observed. The sediment package thins to the NE of the lineament, by $30 \mathrm{~ms}$ TWT (Figure 8c). During the 


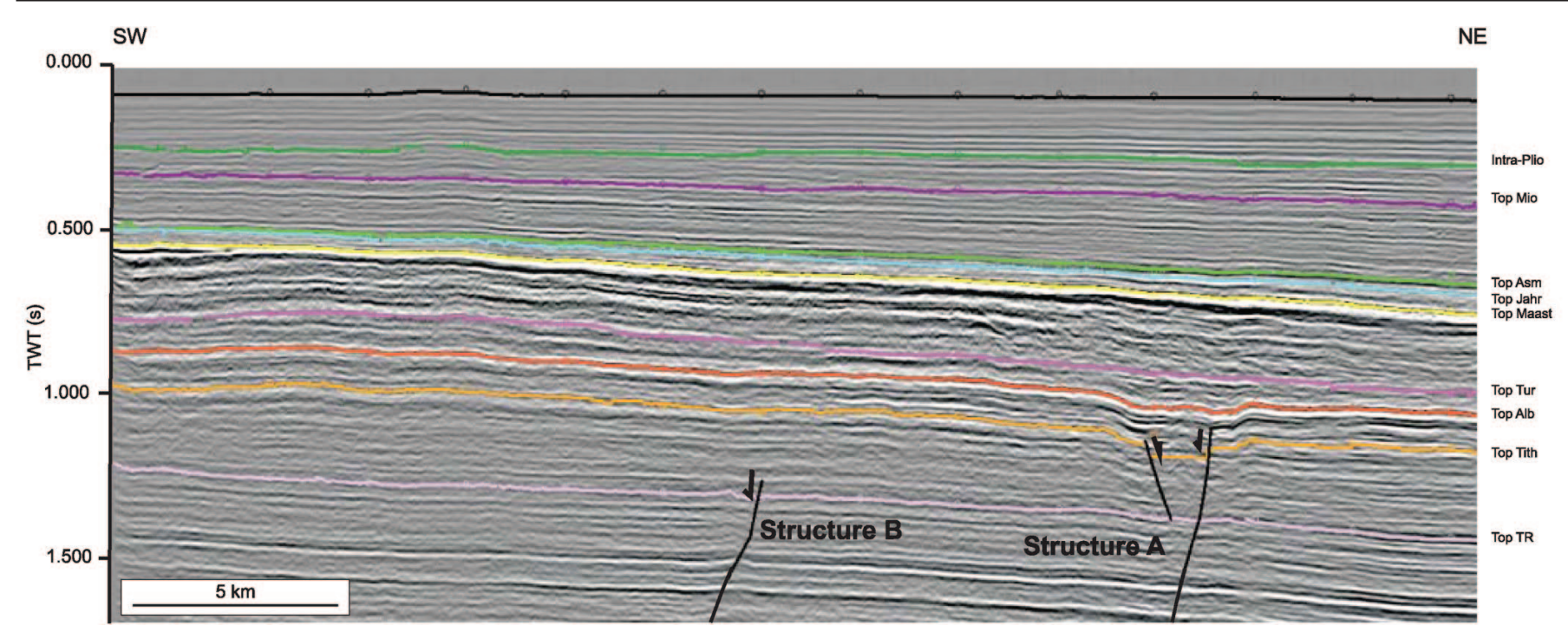

Figure 13. Seismic line over the A and B structures, indicating offsets on these faults during Triassic and Tithonian time. The vertical exaggeration of this line is $c .4 \times$.

Late Cretaceous, any thickness changes related to the A and B fault systems are masked by the development of a distinct zone of thick sediment, trending NW-SE, to the NE of the lineament described above (Figure 8d). Some thinning is also observable southwards from these structures onto the South Pars dome.

The post-Maastrichtian package thickens towards the Zagros Frontal Fault and, based on the available data, displays no thickness variations with respect to the A, B or South Pars Field structures (Figure 9a-c).

\section{Structures in the NE of the dataset}

In the NE of the dataset, the top Triassic time-structure map (Figure 6) illustrates the presence of a series of folds that deform the entire post-Triassic succession. The folds trend NW-SE, and have wavelengths of $16 \mathrm{~km}$ and amplitudes of $60 \mathrm{~ms}$ (TWT) in the NE margin of the dataset towards the Zagros Frontal Fault. The amplitude of these folds decreases southwestwards away from the Zagros Frontal Fault (Figure 14) and such folds are not developed beyond $30 \mathrm{~km}$ to the SW of this fault.

Within this folded zone, a small NW-SE-trending master fault (X structure) similar to the faults associated with the Golshan structure has also been mapped (Figures 6 and 15). The $X$ structure consists of a master fault that dips to the SW and that has a displacement of $20 \mathrm{~ms}$ TWT (downthrow to the SW). The $X$ structure is associated with two antithetic faults that dip to the NE. These faults displace the top Triassic horizon by 0.01 s (downthrow to the NE), but do not offset horizons younger than the top Tithonian horizon.

Lastly, a NE-SW-trending subvertical fault (fault Z) is mapped in the NE corner of the seismic dataset. Subtle downward deflection of reflection events is visible adjacent to this structure and suggests that the fault downthrow is to the east. This fault affects only Albian and younger units. As this structure is located on the edge of the dataset, the full extent of the faulting cannot be identified.

\section{Structural interpretation and timing of deformation}

The regional thickness variations described in the preceding section are interpreted to be related to variations in accommodation linked to syndepositional tectonic activity. Based on the regional structural setting outlined above, syndepositional activity is related to compression-related folding, faulting in the basement and cover, and movement of the Hormuz Complex evaporites.

The $\mathrm{K}$ and $\mathrm{E}$ structures are located along the trace of a prominent NNE-SSW-trending lineament that is spatially coincident with the projected offshore trace of the Kazerun Fault (Figure 16). The type (i.e. normal), sense of offset (i.e. west-dipping) and timing (i.e. Cretaceous) of movement on this fault trend are consistent with those of other NNE-SSW-trending faults such as the Izeh Fault as determined from onshore exposures and seismic studies of salt movement (Sherkati \&

Table 2. Raw data for thickness ratio change across the Golshan structure

\begin{tabular}{|c|c|c|c|c|c|}
\hline Marker & $\begin{array}{l}\text { Dummy well 1, } \\
\text { formation top (TWT) }\end{array}$ & $\begin{array}{l}\text { Column } 1 \\
\text { thickness (s) }\end{array}$ & $\begin{array}{l}\text { Dummy well 2, } \\
\text { formation top (TWT) }\end{array}$ & $\begin{array}{l}\text { Column } 2 \\
\text { thickness (s) }\end{array}$ & $\begin{array}{c}\text { Thickness } \\
\text { ratio }\end{array}$ \\
\hline Sea floor & 0.09 & & 0.09 & & \\
\hline Top Miocene & 0.19 & 0.05 & 0.32 & 0.09 & 0.56 \\
\hline Top Asmari & 0.32 & 0.13 & 0.5 & 0.18 & 0.72 \\
\hline Top Jahrum & 0.34 & 0.02 & 0.53 & 0.03 & 0.67 \\
\hline Top Turonian & 0.57 & 0.17 & 0.83 & 0.17 & 1.00 \\
\hline
\end{tabular}




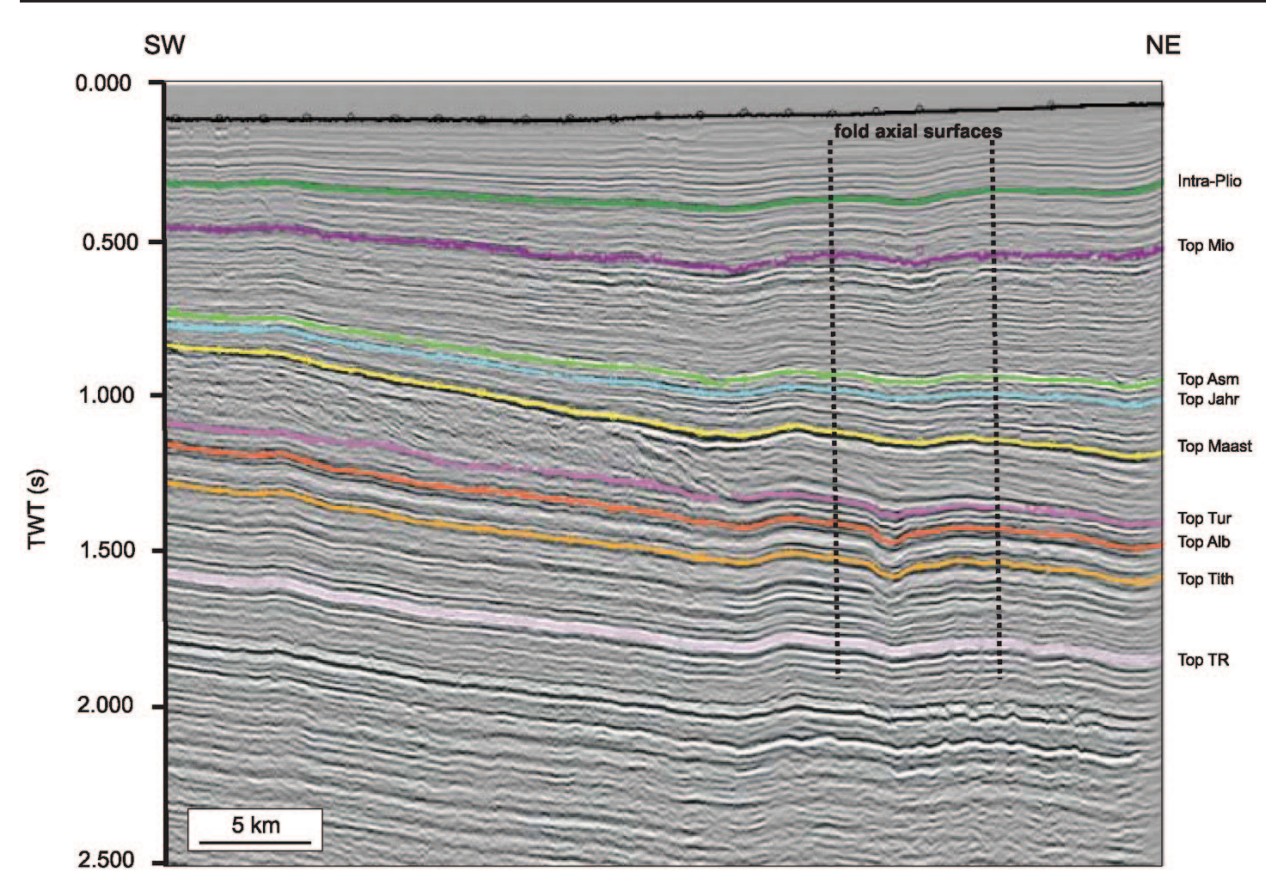

Figure 14. Seismic line crossing the serial folds in the NE of the dataset. The vertical exaggeration of this line is c. $6 \times$.

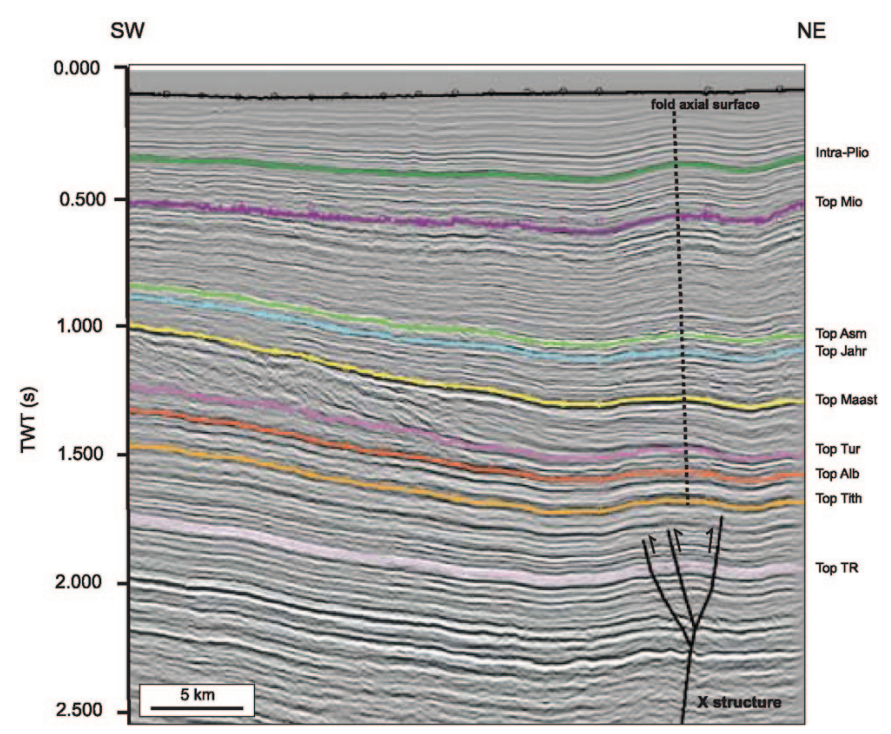

Figure 15. Seismic line over the $X$ structure, indicating minimal offset of the Triassic horizon only. The vertical exaggeration of this line is c. $6 \times$.

Letouzey 2004; Fard et al. 2006; Ahmadhadi et al. 2007; Baaske et al. 2007; Soleimani \& Sabat 2010). Discontinuous variations in thickness (e.g. Figure 8a-d) within the Jurassic and Cretaceous sequences suggest that the offshore Kazerun Fault may be segmented into a series of east-stepping, west-dipping, oblique-slip fault segments, with some downthrow to the west. The Kazerun Fault is also interpreted to be segmented onshore, with the constituent dextral fault strands stepping progressively to the east, in direct continuation of the system described in this study (Sepehr \& Cosgrove 2005).

The WNW-ESE-trending faults of the K-1 fault system may mark the location of a pull-apart basin developed between constituent east-stepping strands. Such pull-apart basins along segmented NNE-SSW faults have been documented to correspond to the locations of salt diapirs (Koyi 1988; Edgell 1996;

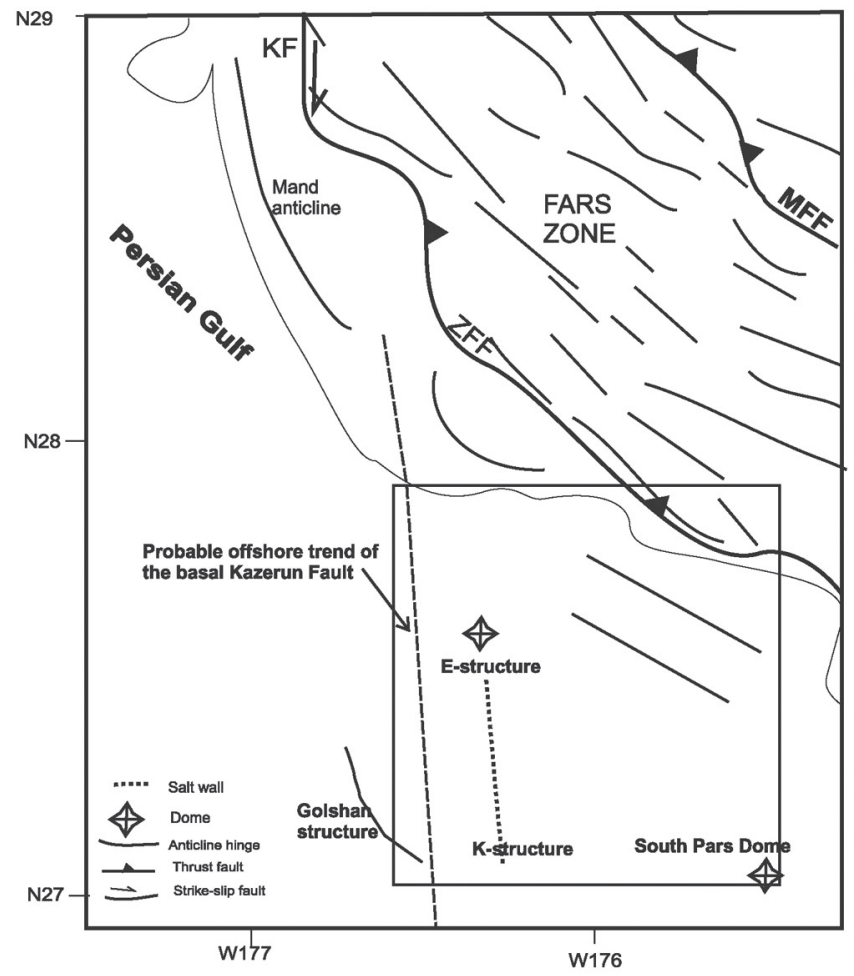

Figure 16. Summary figure (not to scale) illustrating the proposed offshore trend of the basal Kazerun Fault (dashed line) and the spatial relationships of the Golshan, K and E structures to this trend. Dextral movement on this basal fault produces a more diffuse zone of deformation in the overlying, less competent cover rocks.

Talbot \& Alavi 1996; Talbot et al. 2000; Sepehr \& Cosgrove 2005; Sherkati et al. 2005; Callot et al. 2007; Cosgrove et al. 2009). At depth beneath the K-structure faults, chaotic reflectors may be indicative of a salt body. We therefore concur with Baaske et al. (2007) that the K and E structures are salt-cored, and suggest further that movement on the Kazerun Fault during the Early Cretaceous formed pull-apart basins between the fault 
strands. This dilation of the overburden triggered the initial development of the salt diapir ("passive diapirism"; Vendeville \& Jackson 1992; Hudec \& Jackson 2007). Subsequently, the onset of subduction during the Late Maastrichtian triggered compression across the study area and increased uplift on the $\mathrm{K}$ and Golshan structures during this time period (refer to Figure 10). A second pulse of uplift, indicated by a reduced thickness ratio over the $\mathrm{K}$ structure (Figure 10), occurred in the Miocene and waned from the Late Miocene to Recent.

Similarly, observations of thickness changes adjacent to the Golshan fault indicate that this structure initially, during the Early Cretaceous, behaved as a normal fault with downthrow to the SW. As the regional tectonics include large basementinvolved strike-slip faults in this area (Figure 16), we propose that this structure is also part of a pull-apart basin along segments of a basal strike-slip fault, in which passive diapirism occurred, as described above for the $\mathrm{K}$ and $\mathrm{E}$ structural trend. The synkinematic sedimentary fill in the hanging wall of the Golshan fault system was subsequently uplifted and folded, with the associated units producing a geometry characteristic of inversion (Hayward \& Graham 1989). The major inversion event occurred in the Maastrichtian, as evidenced by truncation relationships within the Maastrichtian package. Subsequently, the low-angle onlap of reflection events within the Paleocene-Early Miocene (Figures $11 \& 12$ ), coupled with the changes in thickness ratio (Figure 10), indicates waning movement across the Golshan structure within this time period. Figure 10 indicates that uplift on the Golshan structure increased from the Miocene onwards. Specifically, the thickness variations described across the Golshan, $\mathrm{K}$ and $\mathrm{E}$ structures imply that these structures were most active during the Maastrichtian, which is consistent with results from other seismic interpretation studies in the area (e.g. Fard et al. 2006; Soleimani \& Sabat 2010).

Lastly, the A, B and South Pars structures (Figures 6 \& 13) record similar extension in the Early Cretaceous, presumably as a result of salt movement at depth; these structure are, however, apparently unaffected by the later Maastrichtian or Miocene compressional events.

\section{Discussion and conclusions}

Analysis of a block of 2D seismic data allows a detailed description of the various structural styles present within the Persian Gulf, offshore from the Fars Zone, Iran. Seismic data have been correlated with well data (Swift et al. 1998) and by combining these two data types, it is possible to construct isochron maps of key stratal units, which allow the timing of movement on these structures to be constrained.

The onset of loading related to the Zagros Orogen to the NE is clearly expressed within the study area, with the postMaastrichtian units thickening to the NE. This northeastwards thickening of the post-Maastrichtian units implies rapid subsidence and creation of accommodation space ahead of the advancing orogen. Folds documented within the sediment pile in the NE of the study area (Figures $6 \& 15$ ) show a decrease in amplitude and increase in wavelength away from the $\mathrm{Za}$ gros Frontal Fault. This is characteristic of the propagation of deformation by serial folding away from the collision zone towards the foreland (Blay et al. 1977; Hessami et al. 2001; VitaFinzi 2005; Burberry et al. 2010). The development of serial folds within this part of the Persian Gulf demonstrates the continued propagation of deformation southwestwards from the collision zone towards the foreland.
The E, Golshan and K structures (Figures 6, 7, 11, \& 12) are located to the foreland of the Zagros Frontal Fault and are unrelated to the serial folds discussed above. Not only are they geometrically distinct from orogen advance-related serial folds as above, but they occur in distinctly different locations and have a different temporal development. The locations of all three structures are a function of both Maastrichtian and Miocene-Recent deformation pulses within the Persian Gulf, interacting with the strands of the NNE-SSW-trending, basement-involved Kazerun Fault. Variations in sedimentary thickness across the E, Golshan and K structures indicate two phases of reactivation across the study area. These reactivation phases appear coincident with the known regional compressive events, namely the onset of subduction and associated salt diapirism in the Maastrichtian and the closure of Tethys in the Late Miocene. However, the absolute timing of reactivation events within the study area cannot be constrained because of the scarcity of available biostratigraphic data from the wells used to constrain intraformational horizons, at a resolution below that map-able by industry-standard seismic reflection data. These observations and conclusions are in agreement with conclusions drawn from seismic interpretation by other workers (e.g. Fard et al. 2006; Soleimani \& Sabat 2010) in nearby study areas (see Figure 1 for locations). For example, Soleimani \& Sabat (2010) presented seismic lines showing similar thickness changes within the Late Cretaceous sedimentary sequence across NNE-SSW-trending structures.

This paper presents a database that demonstrates the interaction between Maastrichtian-Recent compression events and pre-existing basement faults such as the Kazerun Fault. At depth within pre-Hormuz Salt basement, the NNE-SSW-trending Kazerun Fault is likely to be a single strand or a number of closely spaced fault strands. In the post-Hormuz "cover" sequence, thickness variations (e.g. Figure 8b) imply that the underlying structure is likely to be segmented and to have been related to a somewhat diffuse zone of deformation, encompassing the Golshan, $\mathrm{K}$ and $\mathrm{E}$ structures within the present study area, and the Mand Anticline and similar structures onshore (Sepehr \& Cosgrove 2005). The deformation history of the Golshan structure revealed by seismic data can be explained without recourse to the intervention of the NNE-SSW-trending Kazerun Fault. However, considering the regional context, we suggest that the deformation of the Golshan structure has been strongly influenced by the underlying Kazerun Fault, as the projected trend of the Kazerun Fault (Figure 16) runs between this and the $\mathrm{K}$ and $\mathrm{E}$ structures. Interestingly, the size, geometry and orientation of the complete Golshan structure bears a striking resemblance to the geometry of the Mand anticline, a major hydrocarbon trap situated onshore to the north of this structure. This study indicates that the interaction between Maastrichtian-Recent compression events and the locations of pre-existing basement faults during the deformation of the Persian Gulf can be studied through the use of 2D seismic reflection data and standard seismic-stratigraphic techniques.

Acknowledgments - We thank GGS ASA for the use of the PC-2000 dataset and permission to publish the results of this study. T. Needham, S. Sherkati and C. Talbot are thanked for thorough and helpful reviews, which greatly improved the paper. C.M.B. acknowledges support from an Imperial College Janet Watson scholarship in support of her doctoral studies. We also thank Seismic Micro Technologies (SMT) for permitting use of Kingdom Suite software through provision of an academic license agreement with Imperial College. 


\section{References}

Aali, J., Rahimpour-Bonab, H., and Kamali, M. R. 2006. Geochemistry and origin of the world's largest gas field from Persian Gulf, Iran. Journal of Petroleum Science and Engineering, 50, 161-175, doi:10.1016/j.petrol.2005.12.004.

Agard, P., Omrani, J. Jolivet, L., and Mouthereau, F. 2005. Convergence history across Zagros (Iran): constraints from collisional and earlier deformation. International Journal of Earth Sciences, 94, 401419, doi:10.1007/s00531-005-0481-4.

Ahmadhadi, F., Lacombe, O., and Daniel, J.-M. 2007. Early reactivation of basement faults in Central Zagros (SW Iran): Evidence from pre-folding fracture populations in Asmari Formation and Lower Tertiary paleogeography. In: Lacombe, O., Lavé, J., Roure, F. M., and Verges, J. (eds.) Thrust Belts and Foreland Basins. Springer, Berlin, 205-228.

Alavi, M. 1994. Tectonics of the Zagros orogenic belt of Iran: new data and interpretations. Tectonophysics, 229, 211-238, doi:10.1016/0040-1951(94)90030-2.

Alavi, M. 2004. Regional stratigraphy of the Zagros fold-thrust belt of Iran and its proforeland evolution. American Journal of Science, 304, 1-20, doi:10.2475/ajs.304.1.1.

Alsharhan, A. S., and Nairn, A. E. M. 1995. Tertiary of the Arabian Gulf-Sedimentology and hydrocarbon potential. $\mathrm{Pa}$ laeogeography, Palaeoclimatology, Palaeoecology, 114, 369-384, doi:10.1016/0031-0182(94)00089-Q.

Baaske, U. P., Mutti, M. Baioni, F. Bertozzi, G., and Naini, M. A. 2007. Using multi-attribute neural networks classification for seismic carbonate facies mapping: a workflow example from mid-Cretaceous Persian Gulf deposits. In: Davies, R. J., Posamentier, H. W., Wood, L. J., and Cartwright, J. A. (eds.) Seismic Geomorphology. Geological Society, London, Special Publications, 277, 105-120.

Bahroudi, A., and Koyi, H. A. 2003. Effect of spatial distribution of Hormuz salt on deformation style in the Zagros fold and thrust belt: an analogue modelling approach. Journal of the Geological Society, London, 160, 719-733, doi:10.1144/0016-764902-135.

Bahroudi, A., and Talbot, C. J. 2003. The configuration of the basement beneath the Zagros Basin. Journal of Petroleum Geology, 26, 257-282, doi:10.1111/j.1747-5457.2003.tb00030.x.

Berberian, M. 1995. Master blind thrust faults hidden under the Zagros folds-Active basement tectonics and surface morphotectonics. Tectonophysics, 241, 193-224, doi:10.1016/0040-1951(94)00185-C.

Beydoun, Z. R., Hughes Clarke, M. W., and Stonely, R. 1992. Petroleum in the Zagros Basin: A late Tertiary foreland basin overprinted onto the outer edge of a vast hydrocarbon-rich PaleozoicMesozoic passive-margin shelf. In: MacQueen, R., and Leckie, D. (eds.) Foreland Basins and Foldbelts. American Association of Petroleum Geologists, Memoirs, 55, 309-339.

Blanc, E. J. P., Allen, M. B. Inger, S., and Hassani, H. 2003. Structural styles in the Zagros Simple Folded Zone, Iran. Journal of the Geological Society, London, 160, 401-412, doi:10.1144/0016-764902-110.

Blay, P., Cosgrove, J. W., and Summers, J. M. 1977. An experimental investigation of the development of structures in multilayers under the influence of gravity. Journal of the Geological Society, London, 133, 329-342, doi:10.1144/gsjgs.133.4.0329.

Bordenave, M. L. 2003. Gas prospective areas in the Zagros domain of Iran and in the Gulf Iranian waters. AAPG search and discovery article, 10040a.

Burberry, C. M, Cosgrove, J. W., and Liu, J.-G. 2010. A study of fold amplification and deformation style using the evolution of the land surface: Zagros Simply Folded Belt, Iran. In: Robin, C., and Leturmy, P. (eds.) Tectonic and Stratigraphic Evolution of Zagros and Makran during the Mesozoic-Cenozoic. Geological Society, London, Special Publications, 330, 139-154.

Callot, J. P., Jahani, S., and Letouzey, J. 2007. The role of pre-existing diapirs in fold and thrust belt development. In: Lacombe, O., Lave, J., Roure, F., and Verges, J. (eds.) Thrust Belts and Foreland Basins. Springer, Berlin, 309-325.
Cosgrove, J. W., Talbot, C. J., and Aftabi, P. 2009. A train of kink folds in the surficial salt of Qom Kuh, Central Iran. Journal of Structural Geology, 31, 1212-1222, doi:10.1016/j.jsg.2009.06.014.

Edgell, H. S. 1996. Salt tectonism in the Persian Gulf Basin. In: Alsop, G. I., Blundell, D. J., and Davison, I. (eds.) Salt Tectonics. Geological Society, London, Special Publications, 100, 129-151.

Fard, I. A., Braathen, A. Mokhtari, M., and Alavi, S. A. 2006. Interaction of the Zagros Fold-Thrust Belt and the Arabiantype, deep-seated folds in the Abadan Plains and the Dezful Embayment, SW Iran. Petroleum Geoscience, 12, 347-362, doi:10.1144/1354-079305-706.

Haynes, S. J., and McQuillan, H. 1974. Evolution of Zagros Suture Zone, Southern Iran. Geological Society of America Bulletin, 85, 739744, doi:10.1130/0016-7606(1974)85<739:EOTZSZ>2.0.CO;2.

Hayward, A. B., and Graham, R. H. 1989. Some geometrical characteristics of inversion. In: Cooper, M. A., and Williams, G. D. (eds.) Inversion Tectonics. Geological Society, London, Special Publications, 44, 17-39.

Hessami, K., Koyi, H. Talbot, C. J. Tabasi, H., and Shabanian, E. 2001. Progressive unconformities within an evolving foreland foldthrust belt, Zagros Mountains. Journal of the Geological Society, London, 158, 969-981, doi:10.1144/0016-764901-007.

Hessami, K., Nilfouroushan, F., and Talbot, C. J. 2006. Active deformation within the Zagros Mountains deduced from GPS measurements. Journal of the Geological Society, London, 163, 143-148, doi:10.1144/0016-764905-031.

Hudec, M. R., and Jackson, M. P. A. 2007. Terra infirma: understanding salt tectonics. Earth Science Reviews, 82, 1-28.

James, G. A., and Wynd, J. G. 1965. Stratigraphic nomenclature of Iranian Oil Consortium Agreement Area. AAPG Bulletin, 49, 2182-2245.

Jassim, S. Z., and Goff, J. C. (eds.) 2006. Geology of Iraq. Dolin, Prague; Moravian Museum, Brno.

Konyuhov, A. I., and Maleki, B. 2006. The Persian Gulf Basin: Geological history, sedimentary formations and petroleum potential. Lithology and Mineral Resources, 41, 344-361, doi:10.1134/ S0024490206040055.

Koop, W. J., and Stoneley, R. 1982. Subsidence history of the MiddleEast Zagros Basin, Permian to Recent. Philosophical Transactions of the Royal Society of London, Series A, 305, 149-168, doi:10.1098/ rsta.1982.0031.

Koyi, H. A. 1988. Experimental modeling of role of gravity and lateral shortening in Zagros Mountain Belt. AAPG Bulletin, 72, 1381-1394.

Lees, G. M. 1955. Recent earth movements in the Middle East. Geologische Rundschau, 43, 221-226, doi:10.1007/BF01764105.

McQuarrie, N. 2004. Crustal scale geometry of the Zagros fold-thrust belt, Iran. Journal of Structural Geology, 26, 519-535, doi:10.1016/j. jsg.2003.08.009.

Nadjafi, M., Mahboubi, A. Moussavi-Harami, R., and Mirzaee, R. 2004. Depositional history and sequence stratigraphy of outcropping Tertiary carbonates in the Jahrum and Asmari formations, Shiraz area (SW Iran). Journal of Petroleum Geology, 27, 179-190, doi:10.1111/j.1747-5457.2004.tb00052.x.

O'Brien, C. A. E. 1957. Salt diapirism in south Persia. Geologie en Mijnbouw, 19, 357-376.

Ross, D. A., Uchupi, E., and White, R. S. 1986. The geology of the Persian Gulf-Gulf of Oman region-a synthesis. Reviews of Geophysics, 24, 537-556, doi:10.1029/RG024i003p00537.

Sattarzadeh, Y. Active tectonics in the Zagros Mountains, Iran. PhD thesis, Imperial College, London.

Sattarzadeh, Y., Cosgrove, J., and Vita-Finzi, C. 2000. The interplay of faulting and folding during the evolution of the Zagros deformation belt. In: Cosgrove, J. W., and Ameen, M. S. (eds.) Forced Folds and Fractures. Geological Society, London, Special Publications, 169, 187-196.

Sepehr, M. The tectonic significance of the Kazerun Fault Zone, Zagros Fold-Thrust Belt, Iran. PhD thesis, Imperial College, London. 
Sepehr, M., and Cosgrove, J. W. 2005. Role of the Kazerun Fault Zone in the formation and deformation of the Zagros Fold-Thrust Belt, Iran. Tectonics, 24, doi:10.1029/2004TC001725.

Sepehr, M., and Cosgrove, J.W. 2007. The role of major fault zones in controlling the geometry and spatial organisation of structures in the Zagros Fold-Thrust Belt. In: Ries, A. C., Butler, R. W. H., and Graham, R. H. (eds.) Deformation of the Continental Crust: The Legacy of Mike Coward. Geological Society, London, Special Publications, 272, 419-436.

Sharland, P. R., Archer, R. et al. 2001. Arabian Plate Sequence Stratigraphy. Oriental Press, Manama, Bahrain.

Sherkati, S., and Letouzey, J. 2004. Variation of structural style and basin evolution in the central Zagros (Izeh zone and Dezful Embayment), Iran. Marine and Petroleum Geology, 21, 535-554, doi:10.1016/j.marpetgeo. 2004.01.007.

Sherkati, S., Molinaro, M. de Lamotte, D. F., and Letouzey, J. 2005. Detachment folding in the Central and Eastern Zagros fold-belt (Iran): Salt mobility, multiple detachments and late basement control. Journal of Structural Geology, 27, 1680-1696, doi:10.1016/j. jsg.2005.05.010.

Soleimani, B., and Sabat, F. 2010. Style and age of deformation within the NW Persian Gulf. Petroleum Geoscience, 16, 31-39, doi:10.1144/1354-079309-837.

Stoneley, R. 1981. The geology of the Kuh-e Dalneshin area of southern Iran, and its bearing on the evolution of southern Tethys. Journal of the Geological Society, London, 138, 509-526.

Swift, S. A., Uchupi, E., and Ross, D. A. 1998. Late Cenozoic Geology of the Central Persian (Arabian) Gulf from Industry Well Data and Seismic Profiles. WHOI Technical Memorandum, 01-98.
Talbot, C. J., and Alavi, M. 1996. The past of a future syntaxis across the Zagros. In: Alsop, G. I., Blundell, D. J., and Davison, I. (eds.) Salt Tectonics. Geological Society, London, Special Publications, 100, 89-109.

Talbot, C. J., Medvedev, S. Alavi, M. Shahrivar, H., and Heidari, E. 2000. Salt Extrusion at Kuh-e-Jahani, Iran, from June 1994 to November 1997. In: Vendeville, B. C., Mart, Y., and Vigneresse, J.-L. (eds.) Salt, Shale and Igneous Diapirs in and around Europe. Geological Society, London, Special Publications, 174, 93-110.

Talebian, M., and Jackson, J. 2004. A reappraisal of earthquake focal mechanisms and active shortening in the Zagros Mountains of Iran. Geological Journal International, 156.

Uchupi, E., Swift, S. A., and Ross, D. A. 1996. Gas venting and late Quaternary sedimentation in the Persian (Arabian) Gulf. Marine Geology, 129, 237-269, doi:10.1016/0025-3227(96)83347-0.

Vendeville, B. C., and Jackson, M. P. A. 1992. The rise of diapirs during thin-skinned extension. Marine and Petroleum Geology, 9, 331353, doi:10.1016/0264-8172(92)90047-I.

Vita-Finzi, C. 2001. Neotectonics at the Arabian plate margins. Journal of Structural Geology, 23, 521-530, doi:10.1016/ S0191-8141(00)00117-6.

Vita-Finzi, C. 2005. Serial deformation. Proceedings of the Geologists' Association, 116, 293-300.

Walker, R. T. 2006. A remote sensing study of active folding and faulting in southern Kerman province, S.E. Iran. Journal of Structural Geology, 28, 654-668, doi:10.1016/j.jsg.2005.12.014.

Walpersdorf, A. 2006. Difference in the GPS deformation pattern of north and central Zagros (Iran). Geophysical Journal International, 167, 1077-1088, doi:10.1111/j.1365-246X.2006.03147. 